\title{
SAFEGUARDS ISSUES IN SPENT FUEL CONSOLIDATION FACILITIES
}

W. L. Belew

B. W. Moran

\section{Prepared for the}

U. S. Department of State

Office of Nuclear Technology and Safeguards and for the

U.S. Department of Energy

Office of Safeguards and Security

Prepared by

MARTIN MARIETTA ENERGY SYSTEMS, INC.

Oak Ridge, Tennessee 37831

for the

U.S. DEPARTMENT OF ENERGY

under contract DE-AC05-84OR21400 


\section{DISCLAIMER}

This report was prepared as an account of work sponsored by an agency of the United States Government. Neither the United States Government nor any agency Thereof, nor any of their employees, makes any warranty, express or implied, or assumes any legal liability or responsibility for the accuracy, completeness, or usefulness of any information, apparatus, product, or process disclosed, or represents that its use would not infringe privately owned rights. Reference herein to any specific commercial product, process, or service by trade name, trademark, manufacturer, or otherwise does not necessarily constitute or imply its endorsement, recommendation, or favoring by the United States Government or any agency thereof. The views and opinions of authors expressed herein do not necessarily state or reflect those of the United States Government or any agency thereof. 


\section{DISCLAIMER}

Portions of this document may be illegible in electronic image products. Images are produced from the best available original document. 


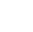


CONTENTS

LIST OF FIGURES $\ldots \ldots \ldots \ldots \ldots \ldots \ldots \ldots \ldots \ldots \ldots \ldots \ldots \ldots \ldots$

LIST OF TABLES $\ldots \ldots \ldots \ldots \ldots \ldots \ldots \ldots \ldots \ldots \ldots \ldots \ldots \ldots \ldots \ldots$

ACKNOWLEDGEMENT $\ldots \ldots \ldots \ldots \ldots \ldots \ldots \ldots \ldots \ldots \ldots \ldots \ldots \ldots$ ix

1. INTRODUCTION $\ldots \ldots \ldots \ldots \ldots \ldots \ldots \ldots \ldots \ldots \ldots \ldots \ldots \ldots \ldots \ldots \ldots \ldots \ldots$

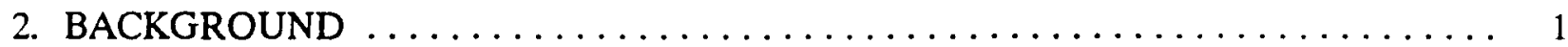

2.1 KEY SAFEGUARDS ISSUES $\ldots \ldots \ldots \ldots \ldots \ldots \ldots \ldots \ldots \ldots \ldots \ldots \ldots \ldots \ldots \ldots$

2.2 IAEA SAFEGUARDS REQUIREMENTS $\ldots \ldots \ldots \ldots \ldots \ldots \ldots \ldots \ldots$

3. OVERVIEW OF SPENT FUEL CONSOLIDATION PROCESSES $\ldots \ldots \ldots \ldots \ldots$

3.1 WET CONSOLIDATION FACILITIES AND EQUIPMENT $\ldots \ldots \ldots \ldots \ldots$.

3.2 DRY CONSOLIDATION FACILITIES AND EQUIPMENT $\ldots \ldots \ldots \ldots \ldots$

4. SAFEGUARDS CONCERNS $\ldots \ldots \ldots \ldots \ldots \ldots \ldots \ldots \ldots \ldots \ldots \ldots \ldots \ldots \ldots$

4.1 RECEIPT AND VERIFICATION OF FUEL ASSEMBLIES $\ldots \ldots \ldots \ldots \ldots .7$

4.2 CONSOLIDATION OF FUEL COMPONENTS ............... 9

4.2.1 Extraction of Pins in Rows with Transfer of All Pins Versus Extraction of Individual Pins with Transfer of Only Spent Fuel Pins . . . . . . . 9

- 4.2.2 Direct Transfer of Pins Versus Transfer with Lag Storage . . . . . . . 10

4.3 CONTAINMENT OF CONSOLIDATED FUEL $\ldots \ldots \ldots \ldots \ldots \ldots \ldots \ldots 11$

4.4 TRANSFER OF CONSOLIDATION CANISTER TO STORAGE $\ldots \ldots \ldots \ldots 11$

4.5 HANDLING OF DAMAGED FUEL COMPONENTS $\ldots \ldots \ldots \ldots \ldots \ldots \ldots 11$

5. POSSIBLE DIVERSION STRATEGIES $\ldots \ldots \ldots \ldots \ldots \ldots \ldots \ldots \ldots \ldots \ldots \ldots \ldots$

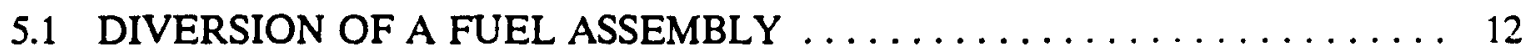

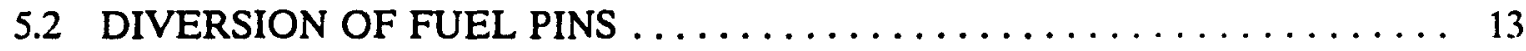

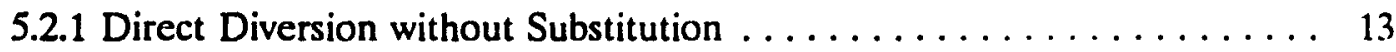

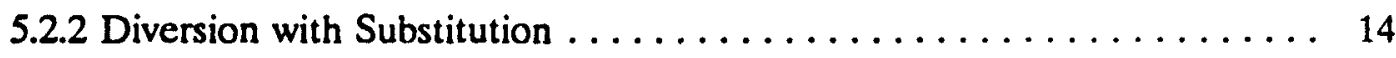

5.2.3 Substitution with Nonfuel Components . . . . . . . . . . . . 14

5.2.4 Diversion from Consolidation Canister $\ldots \ldots \ldots \ldots \ldots \ldots \ldots \ldots$

5.3 DIVERSION OF DAMAGED FUEL $\ldots \ldots \ldots \ldots \ldots \ldots \ldots \ldots \ldots \ldots \ldots$

5.4 DIVERSION OF CONSOLIDATED FUEL CANISTERS $\ldots \ldots \ldots \ldots \ldots \ldots 15$

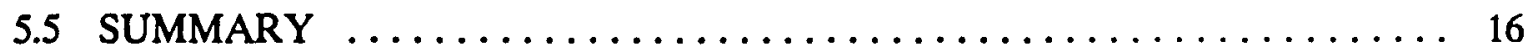

6. POTENTIAL SAFEGUARDS APPROACHES $\ldots \ldots \ldots \ldots \ldots \ldots \ldots \ldots \ldots$

6.1 PERIMETER SAFEGUARDS SYSTEM $\ldots \ldots \ldots \ldots \ldots \ldots \ldots \ldots \ldots \ldots$

6.2 PIN-TRACKING AND VERIFICATION SAFEGUARDS SYSTEM $\ldots \ldots \ldots 19$

6.3 EVALUATION OF POTENTIAL SAFEGUARDS APPROACHES $\ldots \ldots \ldots 20$

7. SUMMARY AND CONCLUSIONS $\ldots \ldots \ldots \ldots \ldots \ldots \ldots \ldots \ldots \ldots \ldots \ldots$ 


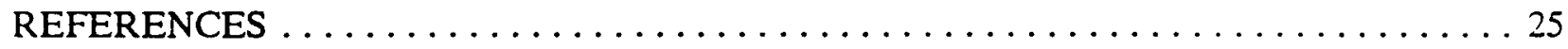

ACRONYMS AND INTITIALISMS $\ldots \ldots \ldots \ldots \ldots \ldots \ldots \ldots \ldots \ldots \ldots \ldots \ldots$

APPENDIX $A \ldots \ldots \ldots \ldots \ldots \ldots \ldots \ldots \ldots \ldots \ldots \ldots \ldots \ldots \ldots \ldots \ldots \ldots \ldots$ 


\section{LIST OF FIGURES}

Figure $\quad \underline{\text { Page }}$

1 Fuel Master consolidation system $\ldots \ldots \ldots \ldots \ldots \ldots \ldots \ldots \ldots \ldots \ldots \ldots \ldots \ldots \ldots \ldots$

2 Floor plan of dry consolidation cell $\ldots \ldots \ldots \ldots \ldots \ldots \ldots \ldots \ldots \ldots \ldots$

3 Potential diversion points in spent fuel consolidation $\ldots \ldots \ldots \ldots \ldots \ldots \ldots \ldots \ldots$ 


\section{LIST OF TABLES}

$\underline{\text { Page }}$

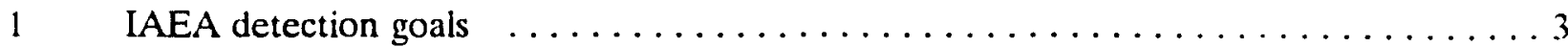

2 Number of fuel pins required to obtain $8 \mathrm{~kg} \mathrm{Pu}$ from typical LWR fucl assemblies $\ldots 3$

3 Safeguards diversion scenarios in spent fuel consolidation facilities $\ldots \ldots \ldots 17$

4 Potential safeguards techniques for spent nuclear fucl consolidation facilities . . . . . 30 


$$
\text { - }
$$




\section{ACKNOWLEDGEMENT}

The authors wish to acknowledge the efforts of the following persons for providing technical information on the design of spent fuel consolidation facilities, for identifying potential safeguards aspects and techniques, and for reviewing this document: C. W. Forsberg, M. H. Ehinger, and J. N. Cooley, Martin Marietta Energy Systems, Inc.; K. K. S. Pillay and E. A. Hakkila, Los Alamos National Laboratory; C. S. Sonnier and D. L. Mangan, Sandia National Laboratories; and D. D. Drayer and G. E. Bosler, on assignment to the U.S. Department of Energy, Office of Safeguards and Security. 


\section{INTRODUCTION}

In the nuclear power industry, the fuel assembly is the basic unit for nuclear material accountancy. The safeguards procedures for the spent fuel assemblies, therefore, are based on an item accountancy approach. When fuel consolidation occurs in "at-reactor" or "away-from-reactor" facilities, the fuel assemblies are disassembled and cease to be the basic unit containing nuclear material. Safeguards can no longer be based on item accountancy of fuel assemblies. The spent fuel pins containing plutonium are accessible, and the possibilities for diversion of spent fuel for clandestine reprocessing to recover the plutonium are increased. Thus, identifying the potential safeguards concerns created by operation of these facilities is necessary. Potential safeguards techniques to address these concerns also must be identified so facility designs may include the equipment and systems required to provide an acceptable level of assurance that the international safeguards objectives can be met when these facilities come on-line. The objectives of this report are (1) to identify the safeguards issues associated with operation of spent fuel consolidation facilities, (2) to provide a preliminary assessment of the safeguards vulnerabilities introduced, and (3) to identify potential safeguards approaches that could meet international safeguards requirements. The safeguards aspects of spent fuel consolidation are addressed in several recent reports and papers, and the reader is encouraged to read these references for additional information. 1.23.45,6

\section{BACKGROUND}

\subsection{KEY SAFEGUARDS ISSUES}

- Spent fuel consolidation technology is being developed for two applications: (1) to increase fuel storage capacities at reactor sites (predominately storage pool consolidation operations) and (2) to minimize the geologic repository and/or monitored retrievable storage capacity required (predominately hot cell consolidation operations). To date, consolidation of spent fuel assemblies has been performed only on a demonstration program scale. As designs for wastc repositories are finalized to reduce long-term storage capacity requirements and as geologic repositories are delayed, or scheduled in the future, the extent to which spent fuel consolidation will be used, will become more clearly defined. Although no country is currently committed to a large-scale spent fuel consolidation program, the effects of this technology on safeguards objectives need to be considered now, and research and development efforts required to provide equipment and techniques for safeguarding these facilities need to be initiated. Some of the key safeguards issues that must be addressed are:

1. Will dismantling of the spent fuel assemblies require measurement of the nuclear material for material accountancy?

2. Can safeguards systems for consolidation facilities be as effective as those currently used for spent fuel storage?

3. Can a safeguards system be devised that does not require verification of individual spent fuel pins?

4. Can the level of safeguards effectiveness required be provided with the safeguards techniques currently available?

This report addresses these issues by reviewing the safeguards-relevant operational procedures of generic designs for wet and dry consolidation facility designs, identifying the safeguards concerns, and suggesting possible safeguards approaches to meet these concerns. 


\section{IAEA SAFEGUARDS REQUIREMENTS}

International Atomic Energy Agency (IAEA) safeguards for fuel assemblies are based on item accountancy and the integrity of the fuel assembly. The quantity of ${ }^{235} \mathrm{U}$ in each fuel pin is measured by the fuel manufacturer, and the quantity of ${ }^{235} \mathrm{U}$ in each fuel assembly is calculated from the values for the pins in the assembly. Therefore, when the fuel assemblies are charged to a power reactor, the quantity of ${ }^{235} \mathrm{U}$ is known for each fuel assembly. When the spent fuel assembly is discharged from the reactor, the quantity of nuclear material is calculated for cach fuel assembly using the fuel manufacturer's and reactor burnup data. The quantity of nuclear material in the spent fuel assembly is established, and item accountancy is satisfactory as long as the fuel assembly integrity can be assured. The spent fuel assemblies are verified during safeguards inspections by item counting, serial number identification, and use of the Cerenkov Glow technique at the spent fuel storage pools. To provide continuous knowledge of item integrity, the spent fuel assemblies are kept under surveillance until the spent fuel is reprocessed or transferred to other storage facilities. Thus, item accountancy for spent fuel assemblies is considered satisfactory because the safeguards measures provide assurance of the integrity of the fuel assembly. The IAEA safeguards procedures for spent fuel assemblies are based on item accountancy and rely on the following assumptions being valid:

1. the fuel assemblies can be treated as identifiable items, rather than as material quantities;

2. assurance of nondiversion can be attained by accounting for all assemblies, not in terms of quantity of uranium or plutonium; and

3. effective safeguards can be based on surveillance of the spent fuel storage area with periodic verification of spent fuel assembly characteristics (e.g., serial or seal numbers and fingerprint

- radiation emissions).

The success of this approach is critically dependent on the IAEA's ability to ensure item integrity. The fuel pin consolidation process removes the fuel pins from the assembly to scparate the nonfuelbearing components from the fuel pins; thus, item accountancy by assembly will no longer be applicable. The removal of the fuel pins from the fuel assembly permits diversion strategies that could be exploited by a proliferating State. Some of the safeguards issues resulting from the disassembly and consolidation of spent fuel are:

1. $\quad$ losing the unique item identifier for fuel assemblies (e.g., assembly scrial number);

2. verifying the quantity of nuclear material contained in spent fuel assemblies and spent fuel canisters;

3. accounting for nuclear material content from broken or damaged fuel pins;

4. losing continuity of knowledge that all nuclear materials are accounted for;

5. distinguishing fuel pins from nonfuel light-water reactor (LWR) components that have the same physical appearance as fuel pins (e.g., water and absorber pins);

6. detecting fuel pins in radioactive waste canisters removed from the site;

7. detecting covert methods for diversion of fuel pins from the process cell and site;

8. maintaining continuous surveillance on a complex operating process systcm; and

9. detecting presence of dummy fuel assemblies and pins that might be substituted for spent fuel.

The IAEA procedures and policies for the safeguarding of spent fuel may need to be reviewed and modified to meet these issues and concerns. The current IAEA safeguards guidance for spent fuel are based on the following considerations: 
1. spent fuel is not "practicably irrecoverable" and should not be eligible for termination of safeguards, and

2. economic considerations should not be accepted as a major deterrent to a diverter. ${ }^{1}$

The IAEA goals for detection of diversion shown in Table 1 are defined in terms of the significant quantity, detection timeliness, and the probability of detecting diversion. The detection goals for spent fuel are based on plutonium because plutonium is a more desirable material for proliferation than low-enriched uranium.

In a fuel consolidation facility, the primary unit of nuclear material accessible for diversion will be the fuel pins. To better establish the safeguards concerns for the purposes of this report, the IAEA detection goals will be defined in terms of the number of fuel pins required to obtain $8 \mathrm{~kg} \mathrm{Pu}$ from fuel assemblies with an average burnup profile. In Table 2, these detection goals are shown as the number of fuel pins for a typical pressurized water reactor (PWR) and boiling-water reactor (BWR) spent fuel assemblies. By selectively diverting pins or assemblies having the highest plutonium content, the required number of pins could be reduced.

Table 1. IAEA detcetion goals

\begin{tabular}{llll}
\hline Material type & $\begin{array}{c}\text { Significant } \\
\text { quantity }\end{array}$ & $\begin{array}{c}\text { Detection } \\
\text { time }\end{array}$ & Detcction probability \\
\hline Plutonium & $8 \mathrm{~kg}$ & $1-3$ months & $>90-95 \%$ \\
Uranium $<20 \%{ }^{235} \mathrm{U}$ & $75 \mathrm{~kg}$ & 1 year & $>90-95 \%$ \\
\hline
\end{tabular}

Table 2 Number of fuel pins required to obtain $8 \mathrm{~kg} \mathrm{Pu}$ from typical LWR fuel assemblies

\begin{tabular}{lcccc}
$\begin{array}{l}\text { Fuel } \\
\text { type }\end{array}$ & $\begin{array}{c}\text { Ave. burnup } \\
\text { GWd/MTIHM }\end{array}$ & $\begin{array}{c}\text { Kg Pu/ } \\
\text { assembly }\end{array}$ & $\begin{array}{c}\text { Number of } \\
\text { pins/assembly }\end{array}$ & $\begin{array}{c}\text { Number of } \\
\text { pins/8 kg Pu }\end{array}$ \\
\hline PWR & $26-40$ & $3-5$ & $126-331$ & $250-800$ \\
BWR & $27-30$ & $1.2-2$ & $47-64$ & $200-420$ \\
\hline
\end{tabular}
content

${ }^{2} \mathrm{GWd}=$ Gigawatt days of electricity produced; $\mathrm{MTIHM}=$ metric tons of initial heavy metal 
The design goal for spent fuel consolidation is at least two assemblies per canister for PWR and BWR assemblies. When the fuel consolidation takes place at the reactor facility, the size of consolidated fuel pin canisters generally will approximate that of a fuel assembly. Thus, the number of fuel pins per canister will be 252 to 662 for PWR assembly consolidation and 94 to 128 for BWR assembly consolidation. To obtain the IAEA detection goal quantity of $8 \mathrm{~kg} \mathrm{Pu}$, a number of pins equivalent to 2 average PWR assemblies (1 PWR consolidated assembly canister) or 5 average BWR assemblies ( $2.5 \mathrm{BWR}$ consolidated assembly canisters) would be required. Fuel consolidation facilities will use a "standard canister" that is sized to contain the pins from 2 PWR assemblies or the equivalent number of pins from BWR assemblies. Each filled consolidation canister would normally contain greater than the IAEA detection goal quantity of $8 \mathrm{~kg} \mathrm{Pu}$.

\section{OVERVIEW OF SPENT FUEL CONSOLIDATION PROCESSES}

Spent fuel consolidation is performed to minimize the cost of spent fuel storage, transportation, and disposal. This is accomplished by reducing the occupied volume through elimination of the grid channels that permit water flow and through removal of the nonfuel-bearing components. For most LWR fuels, consolidation is capable of reducing the fuel volume by a factor of 2 . The fuel pins ultimately are placed in a closely packed array in a canister, and the canister is sealed when full. The canister then becomes the unit of accountability. Broken, or damaged, fuel pins and fuel from the broken pins are accumulated and placed in special containers. The nonfuelbearing components (e.g., control pins, assembly ends, and other hardware) will usually be placed in a separate canister for disposal. All three containers could be the same size as a fuel assembly to facilitate transportation in spent fuel casks. The nonfuel components and unrepairable process equipment may be discarded as low-level waste.

Spent fuel consolidation equipment has been designed for both wet (i.c., storage pool) and dry (i.e., hot cell) operations. Several companies have designed, and have commercially available, equipment to consolidate spent fuel assemblies in a reactor storage pool environment. Consolidation of spent fuel in a hot cell environment also has been demonstrated, and prototype equipment for consolidation facility use is being built. ${ }^{7}$ Although the functional steps are the same for the wet and dry processes, the differences in equipment, operational procedures, and accessibility of fuel pins will have an effect on the applicability and implementation of safeguards procedures and techniques. Therefore, as an aid in evaluating the safeguards concerns for fuel consolidation facilities, typical operating procedures and process steps for both a wet consolidation and a dry consolidation facility were developed and are summarized in this section. ${ }^{8}$ The wet consolidation process, chosen as an example for this report, uses the single pin extraction process with separation of nonfuel- from fuelbearing pins, typical of equipment available commercially. The dry consolidation process, chosen as an example for this report, uses a multiple pin extraction process with no separation of nonfuelbearing pins from fuel pins. Although a single pin extraction process also could be used for the dry process, a process using multiple pin extraction was chosen here for two reasons: (1) to evaluate the higher throughput process, which may be desirable in a dry storage facility receiving a large number of fuel assemblies for processing; and (2) to provide a comparison of the safeguards concerns for the single- and multiple-pin extraction processes.

\subsection{WET CONSOLIDATION FACILITIES AND EQUIPMENT}

Wet consolidation will take place in a fuel assembly storage pool. During consolidation the fuel assemblies and pins will normally remain in a vertical position. The equipment shown in Fig.1 
is typical of the type of equipment that has been designed for the wet consolidation process. Although this equipment is designed for use in wet storage pools, where the fuel assemblies are stored in a vertical position, the equipment could be used at dry consolidation facilities where the storage and processing operations are designed for vertical orientation of the tuel assemblies and consolidation canisters. A brief summary of the fuel consolidation operating steps in module 1 is given below.

1. Spent fuel assemblies are loaded into the left and right work stations in module 1.

2. A spent fuel consolidation canister is placed in the center work station.

3. The end cap of the fuel assembly structure is cut free and removed.

4. The left pin-pulling machine extracts a single pin from the fuel assembly in the left work station and moves to the center work station while the right pin-pulling machine moves to the right work station.

5. The left pin-pulling machine inserts the pin into the fuel consolidation canister in the center work station and the right pin-pulling machine extracts a pin from the fuel assembly in the right work station.

6. The right pulling machine moves to the center station and inserts the pin into the fuel consolidation canister while the left pulling machine extracts a pin from the fuel assembly in the left work station.

7. The above process continues (steps 4 thru 6) until the fuel assemblics are empty or the consolidation canister is full.

8. When the fuel consolidation canister is full, the end caps are attached and the canister is sealed.

The fuel assembly end caps and hardware are transferred to module 2 where they are sheared, compacted, and placed in the hardware consolidation container. Broken pins will be handled by special procedures. The spent fuel assembly hardware and other components that do not contain nuclear material will be compacted in module 2 .

In the wet consolidation process, the storage pool acts as a containment zone for the spent fuel assemblies and consolidation canisters and provides some safeguards benefit from the viewpoint of accessibility of fuel pins. With the type of equipment described, the pin-pulling and consolidation operation normally will be fully automatic. The number and positions of each pin in a fuel assembly, as furnished by the fuel manufacturer, are input into the computerized control system before the start of the consolidation process. Each fuel pin is then assigned a location in the consolidation canister. The system can provide a record of the individual spent fuel pins transferred from each fuel assembly to the consolidation canister. This type of equipment has the following safeguards-relevant design capabilities that earlier types of equipment may not have: (1) the capability to provide one-to-one tracking of spent fuel pins, (2) the capability to separate nonfuel pins from fuel pins by selective removal of individual pins, and (3) an automated operating system that reduces the accessibility of fuel pins for possible diversion activities. 
ORNL DWG 90A-39IR2
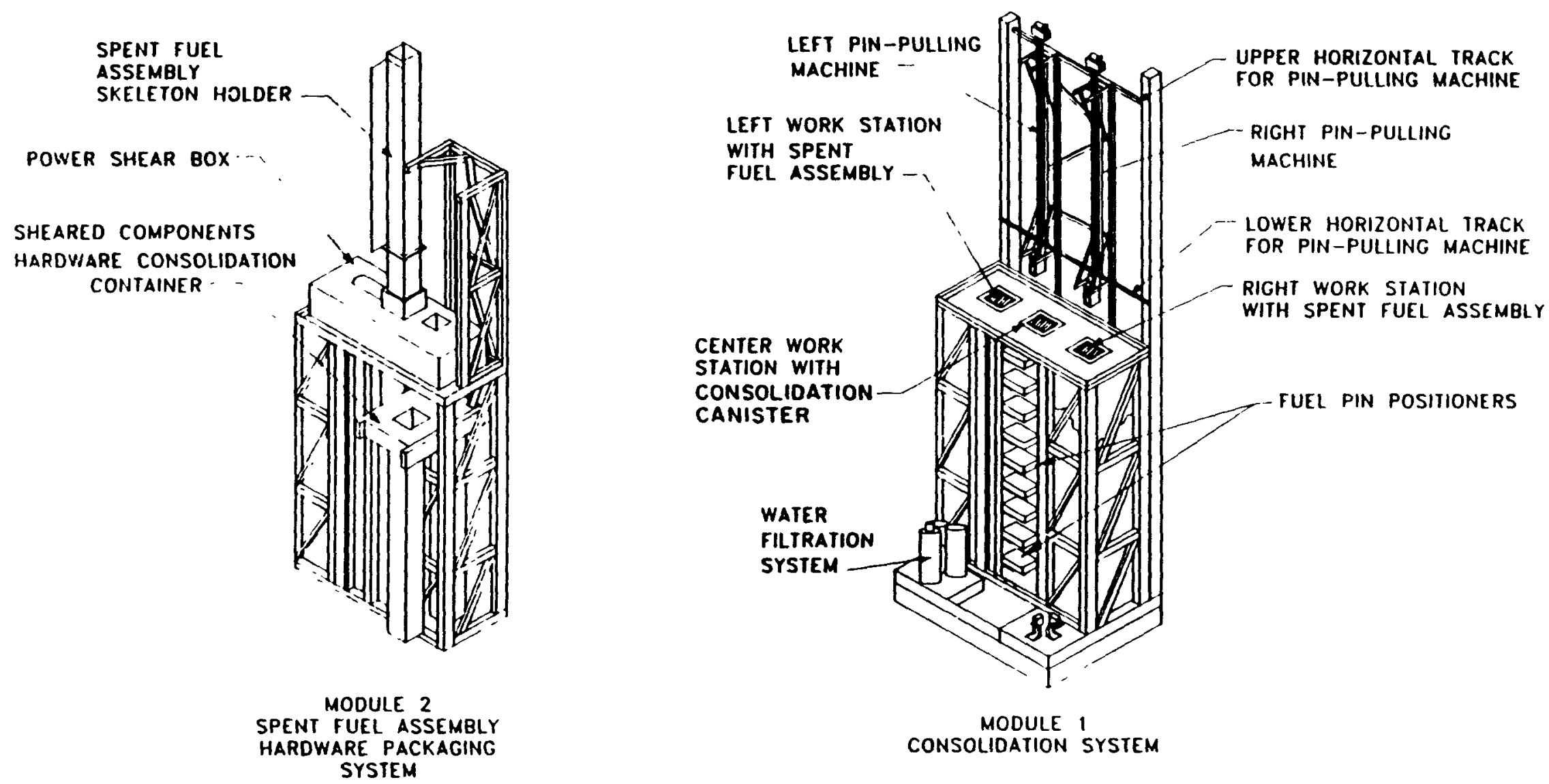

a

Fig. 1. Fuel Master consolidation system. 


\subsection{DRY CONSOLIDATION FACILITIES AND EQUIPMENT}

The dry consolidation process will take place in a hot cell environment that is separated from the receiving, storage, and shipping areas by the hot cell walls. The major safeguards-relevant feature of the process area is the containment of the consolidation process in a hot cell. A floor plan illustrative of a typical dry consolidation facility hot cell area with the separate operating areas identified is shown in Fig. 2. ${ }^{8}$ The operating steps in the consolidation process relevant to safeguards are summarized below:

1. The spent fuel assemblies are transferred into the hot cell vertically, rotated to a horizontal position, and placed in interim storage racks.

2. A fuel assembly is removed from the storage area and placed on the saw table.

3. The end caps are cut from the fuel assembly and are transferred to nonfuel-bearing hardware canisters.

4. The assemblies are placed in a staging area to await pin pulling.

5. The fuel pins are pulled one row at a time into a pin holding system and transferred into a temporary storage and consolidation hopper.

6. When the hopper is full the pins are transferred into a spent fuel consolidation canister.

7. The nonfuel-bearing components are transferred into a nonfuel-bearing component canister.

This type of facility and equipment have several safeguards-relevant features: (1) in the dry fuel consolidation process, the hot cell provides containment for the fuel pins during the consolidation process ; (2) extraction of pins by rows instead of individually will increase the difficulty of verifying individual spent fuel pins; (3) with the type of equipment described, all pins in the fuel assembly are extracted with no separation of nonfuel from fuel pins taking place; and (4) the number of pins pulled and the number transferred to the storage hopper can be recorded to verify that all pins are transferred.

\section{SAFEGUARDS CONCERNS}

To identify and evaluate the safeguards concerns for spent fuel consolidation facilities, the process steps for both the dry and wet consolidation processes were reviewed. In general, the same functional steps take place in the dry and wet processes; however, the significant differences in facility design and equipment operation can cause significant differences in the safeguards vulnerabilities. In areas of the process where the facility design or equipment operation may cause significant differences in the safeguards vulnerabilities, the processes were considered separately and the differences noted.

\subsection{RECEIPT AND VERIFICATION OF FUEL ASSEMBLIES}

On receipt of a shipment, the shipping cask identity is verified, and the cask is placed in interim storage until unloading occurs. The shipping cask may be in interim storage for an indefinite period of time before unloading. During this period, the casks are subject to diversion by switching. Surveillance will likely be required to provide redundant protection unless casks, seais, and identification numbers can be shown to provide adequate safeguards. Data from the fuel manufacturer and the shipper should be available for each fuel assembly to identify (1) the initial uranium content and enrichment, (2) the location of the fuel and nonfuel pins in the assembly, and (3) the burnup and cooling time. These data permit a calculation of the plutonium content, heat 


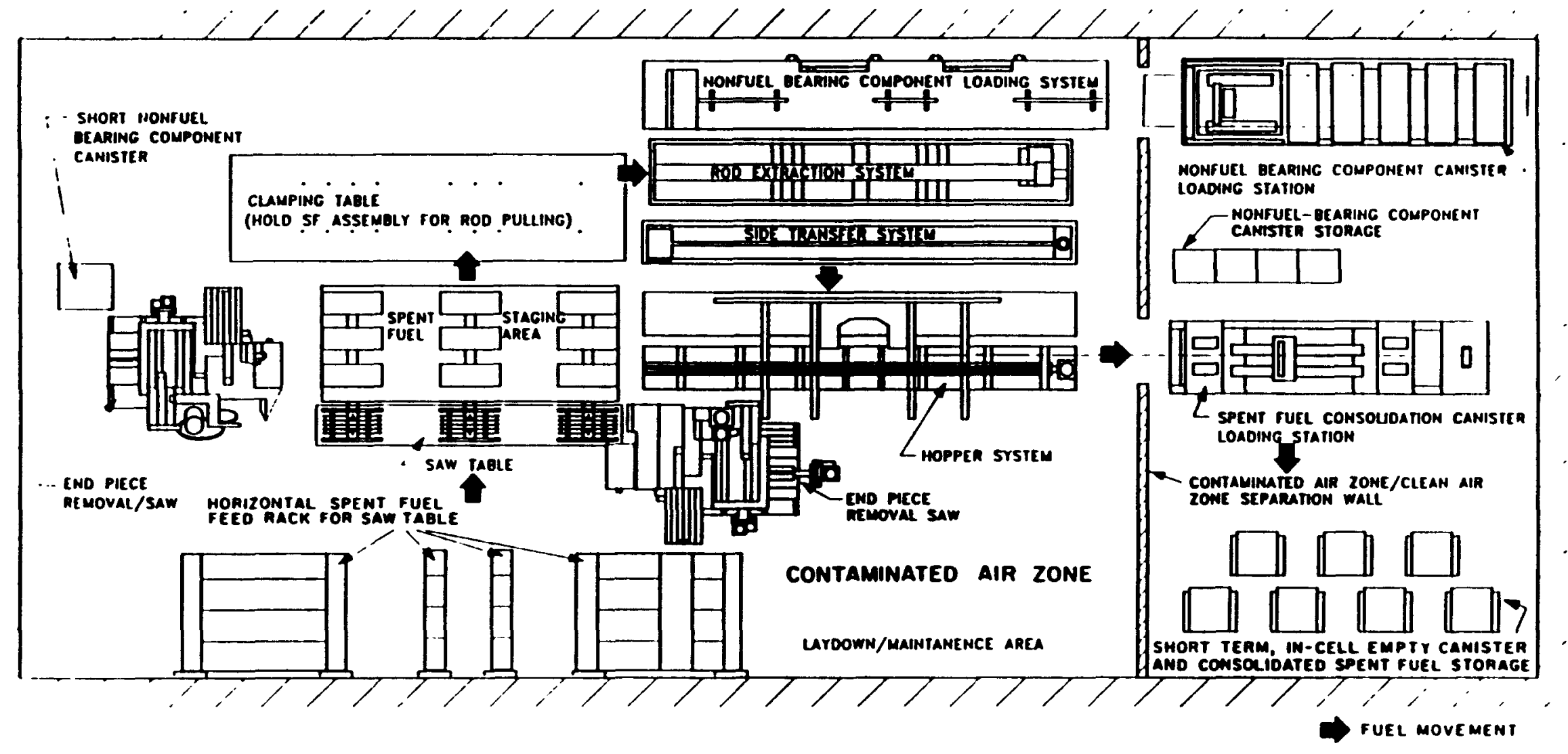

Fig. 2. Floor Plan of Dry Consolidation Cell. 
output, and radioactive emissions of individual and collections of fuel pins. This information is important for both operational and safeguards purposes. The location of each fuel pin is critical to consolidation operations to permit separation of fuel-bearing and nonfuel-bearing components and to minimize waste and spent fuel disposal costs. For safeguards purposes, verifying fuel pin removal and tracking the transfer of the pin to the consolidation canister depend on this information. In wet storage facilities, the cask is unloaded and the fuel assemblies are placed in storage racks. The assembly type and serial number are verified during unloading or shortly after the assemblies are transferred to storage. The fuel assemblies could be held in storage for an indefinite period of time while awaiting processing. The surveillance techniques in use for reactor storage pools also could be used for the fuel assemblies in storage at wet consolidation facilities. In dry storage facilities during unloading, the cask is coupled to a hot cell port, the spent fuel assemblies are unloaded into the hot cell, the assembly type and serial number are verified, and the assembly is transferred to a storage area to await processing. Storage in the hot cell provides a containment barrier and reduces the safeguards risks for diversion from the facility.

The safeguards concerns for receiving and storage of spent fuel at consolidation facilities are similar to those at other spent fuel storage facilities. ${ }^{10}$ However, equipment for dismantling the fuel assemblies is available. The fuel assemblies stored in a consolidation facility therefore, could be considered a more attractive target for diversion of nuclear material than those stored in a reactor

storage pool. Some consideration also must be given to the long-term disposition of the spent fuel. If the reprocessing option is chosen, then safeguards on spent fuel have a definite termination point. If long-term storage in a geologic repository is the option chosen, (1) safeguards will be necessary for a longer period, (2) the spent fuel will not be readily verifiable, and (3) redundant containment and surveillance techniques may be required. ${ }^{11}$

- In general, the vulnerability to diversion is relatively low at this point because the fuel assemblies remain intact. One possible scenario involves substitution of a dummy fuel assembly for a stored fuel assembly with the same serial number. However, the current practices for item accountability and surveillance should provide effective safeguards against this scenario.

\subsection{CONSOLIDATION OF FUEL COMPONENTS}

The basic variations in equipment design and operating procedures for removing fuel pins in wet and dry consolidation facilities presented in Sect. 3 have a significant effect on safeguards concerns and the effectiveness of applicable safeguards techniques. Pins may be removed from the assemblies one at a time or in rows. The pins may be directly transferred to the consolidation canister or they may be assembled in a closely-packed array before being transferred into the canister. Two specific differences in operating procedures of particular importance to safeguards are:

1. extraction of pins in rows with transfer of all pins versus extraction of individual pins with transfer of only spent fuel pins, and

2. direct transfer of the pins to the consolidation canister versus transfer with lag storage of the pins.

The effect of these variations on safeguards vulnerabilities are discussed in the following sections. 
4.2.1 Extraction of Pins in Rows with Transfer of All Pins Versus Extraction of Individual Pins with Transfer of Only Spent Fuel Pins

In the example dry consolidation process, all pins in the fuel assembly are extracted in rows. No separation of nonfuel-bearing from fuel-bearing pins takes place. In this mode of operation, verification of individual fuel pins will be difficult and may present a significant safeguards concern. However, nonseparation of the pins permits accountability by total number of pins because all pins are treated alike. Verification that all fuel-bearing pins were transferred to the consolidation canister could be achieved through verification that all pins were removed from the assembly and placed in the canister. The accountability system could count the pins "in" when they are removed from the fuel assemblies and the number of pins "out" as they are transferred to the fuel consolidation canisters. Any discrepancies in the number of pins would produce a safeguards anomaly. The IAEA may have difficulty accepting the State accounting system's statement that all spent fuel pins were transferred without independent verification. Although diversion of fuel pins without substitution might be difficult, the accountability system could be programmed to miscount pins. Consolidation systems that pull rows of pins are expected to process 4 to 5 PWR or 9 to $11 \mathrm{BWR}$ assemblies per shift. The large number of fuel pins processed could make safeguards techniques dependent on surveillance or observation difficult to implement.

The example, wet consolidation system is a vertically oriented system that extracts fuel pins into a transfer tube and transfers the pins into consolidation equipment that holds the pins unwarped in a closely packed array. The spent fuel pins are extracted individually from the fuel assembly and transferred directly to the fuel pin consolidation canister. The nonfuel pins remain with the other nonfuel components and are chopped or crushed to reduce their volume before packaging in a canister. The key safeguards issue in this design is correct identification of the fuel pins in the fuel assembly. The consolidation facility would depend on shipper's data and/or fuel fabrication design information to locate fuel pins in the assembly. Simple falsification of data, or inadvertent errors in data entry, could result in absorber pins being identified as fuel pins or fuel pins erroneously being identified as nonfuel-bearing pins. Thus, this design introduces a concern because the fuel pins could be placed in nonfuel-bearing canisters and transferred to storage as nonnuclear material components on which safeguards are not applied. This diversion would be masked by the placement of nonfuelbearing pins in the spent fuel canister.

Although the transfer of all pins without separation of the fuel and nonfuel pins may be more desirable from a safeguards viewpoint, efficient use of space in the fuel consolidation canister is sacrificed; therefore, this procedure may not be used as a normal operating practice.

\subsubsection{Direct Transfer of Pins Versus Transfer with Lag Storage}

After extraction, the pins are placed into the closely packed array in a storage hopper. The storage hopper holds fuel pins from different assemblies until the number required to fill a consolidation canister is accumulated. When the hopper is full, the pins are pushed into the canister. Transfer with lag storage introduces additional concerns by increasing the time the fuel pins are accessible for diversion and by accumulating quantities of material from different fuel assemblies before transferring them to the fuel pin canister. The lag storage bin could be a major safeguards concern if not carefully monitored.

The possibility of substituting nonfuel-bearing pins for fuel pins exists. Nonfuel-bearing pins could be placed in lag storage and fuel pins diverted to nonfuel-bearing storage containers. Once the pins are in the wrong canister, identification of the source of the individual pins would become difficult because keeping track of individual pins in the lag storage bin might not be possible. The 
design of the consolidation equipment and process cell could be developed to facilitate the hiding and substitution of dummy pins for fuel pins. Dummy pins would have to be prepared in advance and hidden until used, and the diverted fuel pins would have to be hidden until they could be removed from the process cell. Direct transfer of individual pins from the assembly to the consolidation canister provides the simplest transfer path and the fewest opportunities for substitution.

\subsection{CONTAINMENT OF CONSOLIDATED FUEL}

When a consolidation canister is filled, the canister is sealed. Until the canister is sealed, pins in the canister could be removed without evidence of the removal. Sealing of the canister may occur in an area separated from the consolidation process area. Safeguards procedures will be required to verify that no pins are removed from the canister before sealing. Verification of the canister contents to identify nonfuel-bearing pins and to verify the total number of spent fuel pins may be required.

Nonfuel-bearing canisters will be sealed when filled. Verification of the absence of nuclear material in these canisters also should be required.

\subsection{TRANSFER OF CONSOLIDATION CANISTER TO STORAGE}

After sealing, the filled fuel- and nonfuel-bearing canisters will be placed in casks and transferred to a storage area. The nonfuel-bearing canisters may be identical to the spent fuel canisters. Diversion by substituting nonfuel-bearing canisters for spent fuel canisters before sealing in a cask is feasible. A technique for monitoring fuel-bearing casks to verify the presence of the appropriate number of fuel-bearing canisters would be needed. Verification of the absence of nuclear material in the nonfuel-bearing casks may be required.

\subsection{HANDLING OF DAMAGED FUEL COMPONENTS}

Broken and damaged fuel pins will be handled by special equipment and procedures in the consolidation facilities. Pellets and broken pins would be accumulated until a sufficient quantity was collected to warrant removal from the consolidation area. The damaged fuel would be identified as nuclear material, placed in special canisters for broken fuel pins, and removed from the consolidation process area. The quantity of nuclear material in these canisters would be difficult, if not impossible, to determine from records.

Nonnuclear material from the consolidation process would be placed in nonfuel-bearing canisters, or process waste containers, as appropriate. Any canister or package leaving the facility possibly could contain nuclear material from broken spent fuel pins and could be a significant safeguards concern.

\section{POSSIBLE DIVERSION STRATEGIES}

Spent fuel consolidation facilities are typically designed to operate on one-day cycles: one shift performs material transfer and maintenance operations; the other two shifts perform the fuel consolidation operations. Diversion activities during the maintenance shift must be considered in addition to routine process shift operations. In considering the possible diversion strategies that a national diverter might use in a fuel consolidation facility, the following alternatives were reviewed:

1. diversion of a fuel assembly,

2. diversion of single fuel pins, 
3. diversion of broken fuel pin parts, and

4. diversion of filled consolidated fuel canisters.

Seven example diversion scenarios were identified as representative of the numerous diversion paths one could devise. The diversion scenarios apply to both the wet and dry consolidation processes, except as noted. These are represented schematically in Fig. 3 and discussed below.

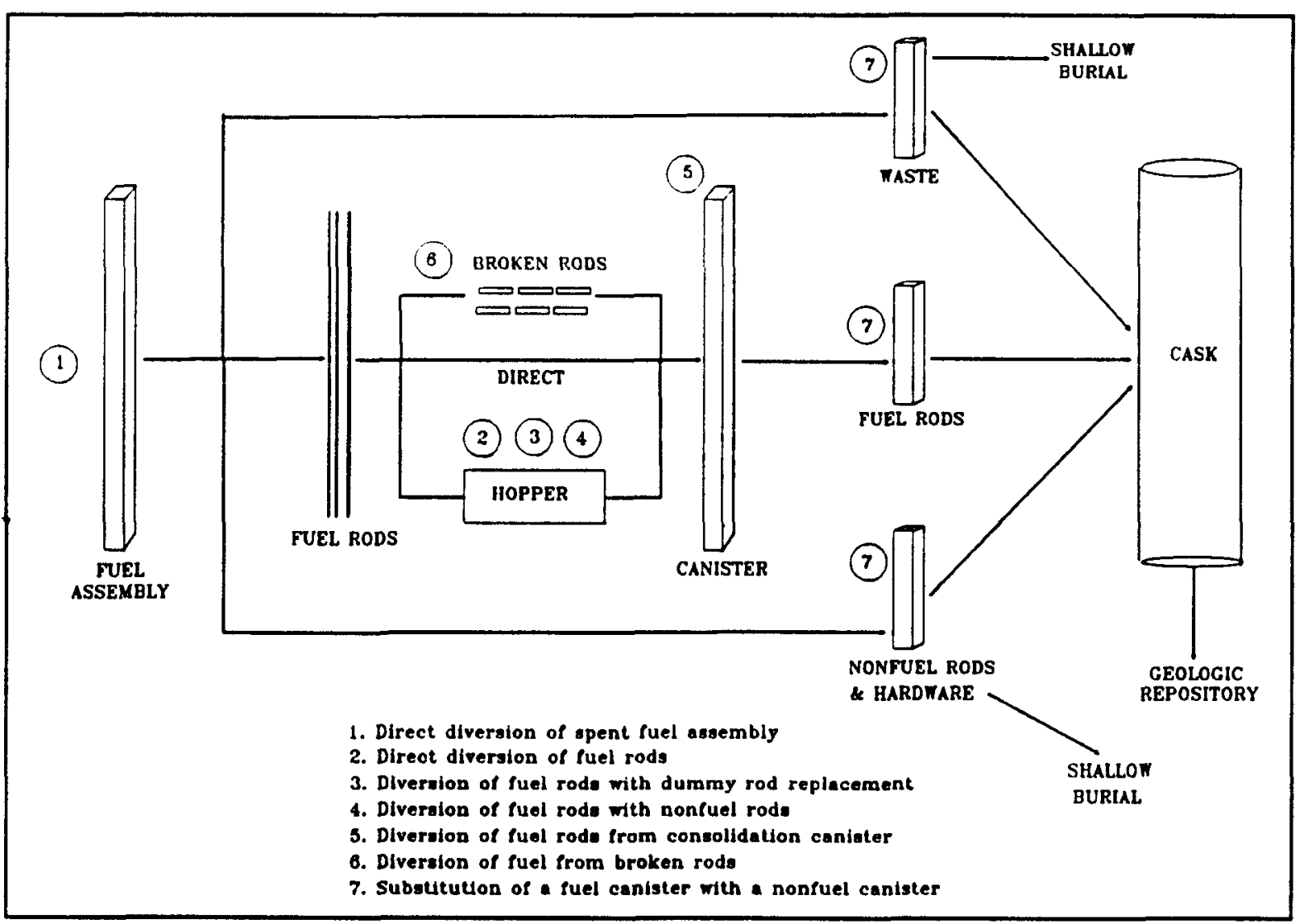

Fig. 3. Potential diversion points in spent fuel consolidation

\subsection{DIVERSION OF A FUEL ASSEMBLY}

Scenario 1: The operator has clandestinely placed a dummy fuel assembly in the fuel assembly receiving bay. During unloading of the spent fuel transport/storage cask in the receiving bay, the dummy assembly is substituted for a fuel assembly and the fuel assembly is left in the cask. At a later time, the diverted fuel assembly is retrieved from the cask and shipped for reprocessing. 
The potential for diversion of a fuel assembly by substituting a dummy assembly by the shipper is recognized to exist at spent fuel handling facilities and is addressed in current IAEA safeguards procedures. Because of the size of the assembly and radiation level associated with a spent fuel assembly, diversion is difficult and can be detected by equipment and procedures presently available at spent fuel storage facilities (i.e., surveillance and radiation monitoring). The safeguards equipment and procedures used for these facilities are extensively described in the report of Working Group Number 1 of the Large Scale Reprocessing Plant Safeguards Program (LASCAR). ${ }^{10}$ New safeguards techniques may not be required as long as the fuel assembly remains intact.

\subsection{DIVERSION OF FUEL PINS}

In the fuel consolidation process the fuel assembly will lose its identity, and the quantity of nuclear material in the assemblies can no longer be measured. Accountability will switch to the pin or fuel pellet (if broken pins) level, and the pins may not have easily read identification numbers. These vulnerabilities create four scenarios for the diversion of nuclear material from the consolidation process:

1. the direct diversion of pins without substitution,

2. the diversion of pins with substitution using dummy pins,

3. the diversion of fuel pins as nonfuel components and substitution of nonfucl pins as nuclear material, and

4. the diversion of pins from unsealed consolidation canisters.

\subsection{Direct Diversion without Substitution}

Scenario 2: A pin consolidation storage hopper is designed to have a bottom that retracts in excess of the distance required to collect sufficient pins for filling a consolidation canister. Each time the hopper is filled an extra row of pins, beyond what is required to fill the consolidation canister, is added to the hopper. During the maintenance and transfer shift, the collected rows of pins are transferred to an unrecorded consolidation canister.

Operations in the consolidation cells will consist of many activities (e.g., assembly head removal, pin pulling, pin consolidation, and system maintenance) occurring continuously and, perhaps, simultaneously. Some of the consolidation activities will involve transferring the fuel pins into hoppers or transfer devices where they will be completely obscured from view. Additional remote manipulators will be available in the cell area for the performance of maintenance and repair activities. The assumption must be made that a State intent on diverting spent fuel could design systems to clandestinely remove fuel pins from the consolidation system. These systems could be designed to by-pass detection by the internal pin counters, or the pin counters could be programmed to miscount the number of pins.

Three principal flows of materials will leave the consolidation process: consolidated spent fuel (e.g., intact pins, broken pins, and consolidation canisters), assembly hardware (e.g., assembly skeleton, end caps, and nonfuel pins), and consolidation equipment (e.g., saw blades, drill bits, and unrepairable equipment). The nonfuel materials and wastes removed from the cell would all provide pathways for the removal of the diverted fuel pins. In addition, diverted fuel could be removed through utility and other ports in the walls of the hot cell or in the empty containers used to transfer materials into the process cell. Because of the presence of cutting equipment in the process cell, fuel pins could be cut to lengths that facilitate removal from the cell. Removal of the diverted spent fuel most likely 
would occur during the maintenance and transfer shift when activities are less routine and transfers to and from the cell are occurring.

\subsection{Diversion with Substitution}

Scenario 3: Dummy spent fuel pins are transferred to the consolidation process area in an "empty" consolidation canister during the maintenance and transfer shift. The dummy pins are then "installed" in the process area. During pin pulling, a dummy pin is "pulled" along with a fuel pin. Before the pins are counted, a fuel pin is removed from the consolidation system and stored for removal during the maintenance and transfer shift. During that shift, the diverted pins are passed through a utility port in the hot cell wall.

Diversion of fuel pins with replacement of the pins with dummy pins would be performed to defeat potentially effective pin counting systems. Dummy pins could be brought into the process area in association with the empty canisters or other material and equipment. During consolidation system startup, dummy assemblies and pins will be necessary for cold testing of the equipment and, therefore, also could be available for diversion of nuclear material. Removal of the diverted pins could be performed as described in Sect. 5.2.1.

\subsubsection{Substitution with Nonfuel Components}

Scenario 4: During fuel pin removal, the operator pulls absorber pins from the assembly and transfers them to the lag storage bin or the fuel consolidation canister. A like number of fuel

- $\quad$ pins are left in the assembly and are transferred to the nonfuel-bearing component canister. The nonfuel-bearing canister is removed from the process cell and stored as nonnuclear wastes for which safeguards are not applicable. At a future date, the fuel pins are recovered from the waste canister. The number of pins accounted for is correct and the only unusual activity necessary is the improper identification of fuel pins on removal from the fuel assembly.

The number and location of fuel pins in an assembly should be known from the shipper's and manufacturer's data. However, because other pins that are physically similar or identical to the fuel pins also may be in the assembly, verifying that the pins removed are fuel pins will be difficult or impossible by using normal surveillance techniques.

Identification of fuel pins in the fuel assembly before the removal step is a major area of safeguards concern. The movement of the fuel pin extraction equipment probably will be controlled by a computer programmed to extract pins from locations indicated by the fuel assembly design data as containing fuel pins. Relying on this data to identify the fuel pins without a verification technique would not provide, in general, acceptable safeguards assurance. A method for verification of the location and number of fuel pins in the assembly is highly desirable and may be required to provide adequate safeguards assurance that all fuel pins are accounted for.

To detect diversion by this path, each canister might have to be monitored to verify the number of fuel pins in the canister before it is closed and sealed. Assurance also would need to be provided that all waste and empty canisters transferred from the storage facility are monitored to detect spent fuel pin presence. 


\subsubsection{Diversion from Consolidation Canister}

Scenario 5: Following removal of a filled consolidation canister from the withdrawal port and before sealing, the remote manipulators are used to pull several pins from the canister. The pins are transferred to an empty consolidation canister that is "awaiting" connection to the withdrawal port. The filled consolidation canister is sealed. During the maintenance and transfer shift, the filled canisters and the diversion canister are removed from the consolidation facility.

When the consolidation canister is full, the canister will be disconnected from the withdrawal port and an end cap will be welded on the canister. While the canister remains unsealed, fuel pins could be removed and transferred to a different container. Because the canister would be sealed immediately following the diversion, no opportunity would be available to recount the number of contained pins. This diversion is potentially credible; however, the size of the withdrawal and welding cell might severely restrict the capability to withdraw pins from the canister. Removal of a pin may be detectable using surveillance techniques.

\subsection{DIVERSION OF DAMAGED FUEL}

Scenario 6: Broken or damaged fuel pins are placed in nonfuel-bearing waste containers. The waste containers having spent fuel are marked by the diverter and retrieved after removal from the process cell.

- In the consolidation process, broken or damaged fuel pins periodically will be generated and will require special handling procedures. These fuel pins will be subtracted from the total count of the number of pins pulled for consolidation. The broken pins, and any loose fuel, will be accumulated and placed in special canisters. Accountability of the material cannot be performed based on the quantity of contained nuclear material because the quantity of nuclear material is not accurately known. Nuclear material from the broken pin canister could be removed from the process cell without detection because of the large uncertainties in (1) determining the quantity of nuclear material that should be present and (2) measuring the quantity of nuclear material that is actually present. The number of broken or damaged fuel pins is low and is decreasing in frequency in newer fuel assemblies. Diversion of a significant quantity of plutonium by this means would take an undetermined period of time. Therefore, although diversion of spent fuel from broken pins is functionally attractive, collecting parts of broken fuel pins would be an unlikely diversion scenario because of the small quantity of material available. An unusually high quantity of "broken fuel" might be a useful indicator of a diversion attempt, or at least an instance requiring additional investigation.

\subsection{DIVERSION OF CONSOLIDATED FUEL CANISTERS}

Scenario 7: Following removal of a consolidation and a nonfuel-bearing canister from the process cell, the operator switches canisters, places the nonfuel-bearing canister in the fuel storage cask, and transfers the fuel-bearing canister to nonnuclear waste storage. At a later time, the fuel-bearing canister is retrieved and submitted for reprocessing.

Fuel- and nonfuel-bearing canisters may be similar in appearance and size to facilitate transportation in shipping casks. Both canisters will be very radioactive and will require similar handling (however, the spent fuel produces higher levels of radiation and decay heat). A State intent 
on diverting the spent fuel could design the two canisters to be identical and could remove the canisters from the process cell through the same transfer cell. These actions would facilitate switching the canisters during cask loading operations. This diversion strategy represents a credible vulnerability and requires monitoring of all canisters and waste packages for nuclear material before transfer from the consolidation facility.

\subsection{SUMMARY}

The diversion scenarios identified are presented and rated in Table 3. The ratings of high, medium, and low are subjective and only indicate the relative probability of success of a diversion by that scenario. These ratings assume that the safeguards procedures are limited to current IAEA practices of surveillance and serial number verification for spent fuel assemblies. These ratings should not be taken as a criticism of the IAEA procedures, but rather, as confirmation of the earlier conclusion by the IAEA that new safeguards approaches are required to deal with spent fuel rod consolidation before these operations become widely used.

The probability of diversion of a spent fuel assembly is considered low because of the safeguards procedures that are currently available. The identification of the fuel assemblies by serial number, verification by the Cerenkov Glow technique, and assurance of integrity during storage by surveillance techniques can provide adequate safeguards for the intact fuel assemblies.

The three diversion scenarios rated "High" deal with individual fuel pins. The high rating reflects the fact that current safeguards systems are not designed for detection of individual fuel pin diversion. A major safeguards concern for a spent fuel consolidation facility will be the diversion of individual spent fuel pins. Development of safeguards techniques to verify individual spent fuel pins and to monitor flows of material from the facility for nuclear material may be required to provide adequate safeguards in the consolidation process area. However, the large number of fuel pins that must be diverted to obtain a significant quantity of plutonium (i.e., $8 \mathrm{~kg}$ ) increases the opportunity for detection to take place; the protracted character of the diversion lessens the safeguards requirements for the timely detection of each diversion act. Thus, although the probability of successful diversion of individual pins is high, probability of successful diversion of a significant quantity of nuclear material may be low.

The diversion of fuel pins from a consolidation canister is rated medium because the actions required to extract the pins would require several planned operations using major pieces of process equipment. These actions normally would not be included in operating procedures and could be detected using current safeguards surveillance techniques. The diversion of broken fuel parts is rated high; however, the low quantity of nuclear material involved should not normally constitute an attractive target. The diversion of fuel pin canisters by substitution with nonfuel-bearing component canisters is rated low because (1) the moving and concealing of canisters in the process area would be difficult and (2) the surveillance systems currently used for spent fuel assembly storage are potentially applicable to this area.

\section{POTENTIAL SAFEGUARDS APPROACHES}

Safeguards for spent fuel currently depend on a continuous knowiedge of the fuel assembly integrity from the time it leaves the reactor and enters the spent fuel storage pool until the fuel is shipped for reprocessing or permanent storage. This is accomplished primarily by containment and surveillance measures. In considering potential safeguards concepts for spent fuel consolidation 
Table 3. Safeguards diversion scenarios in spent fucl consolidation facilities

Probability of diversion
success $^{2}$

Direct diversion of a spent fuel assembly

Low

or substitution of dummy fuel assemblies for

real fuel assemblies

Direct diversion of fuel pins during pin

High

consolidation without replacement

Diversion of fuel pins during consolidation

High

with dummy pin replacement

Diversion of fuel pins through substitution

with nonfuel pins

High

Diversion of fuel pins from a fuel

Medium

consolidation canister

Diversion of broken fuel pin parts

High $^{\mathrm{b}}$

Substitution of fuel pin canisters for

Low nonfuel-bearing component canisters

Using current IAEA safeguards techniques.

${ }^{b}$ However, limited quantity of material would normally make this scenario unattractive.

facilities in this report, the measures currently in place at reactor storage pools are assumed to be applied in fuel assembly and cask storage areas of the consolidation facility.

The primary safeguards concern in the consolidation process area is verification that all spent fuel pins were removed from the spent fuel assembly and transferred to the fuel consolidation canister. All consolidation systems will have some mechanism for handling single pins that are either damaged or otherwise unacceptable for consolidation. A "trickle diversion" pin by pin could be possible, and the safeguards design should be able to detect single pin diversion. This could possibly be accomplished by continuous observation during consolidation operations by an inspector. The manpower available for this type of safeguards activity is limited; and continuous observation, if implemented, realistically could not be expected to be effective because of the complex operations involved in the consolidation process. The complexity of the process (i.e., frequent movement of various pieces of equipment and fuel assembly components) also may preclude the effective use of conventional video surveillance techniques. Thus, further development and application of existing 
safeguards techniques and development of new techniques may be necessary to provide an acceptable level of safeguards for spent fuel consolidation facilities.

To design a detailed safeguards system for a facility, one needs to know the detailed operating procedures of the facility; the safeguards approach for a facility will be specific to that facility. The safeguards approaches described here are (1) generic in nature and (2) illustrative of technologies that could be used. The potential safeguards approaches suggested are only conceptual and are meant to focus attention on the problem areas in providing safeguards for spent fuel consolidation facilities.

Two different approaches or a combination of the two approaches could be used: (1) a perimeter safeguards system and/or (2) a pin-tracking and verification system. Examples of the safeguards activities that may be required for each of these two approaches are outlined.

In each of these approaches, the assumption is made that continuous knowledge of the spent fuel assembly integrity is available and that the spent fuel assembly enters the consolidation process with safeguards intact.

In the ideal safeguards system, a measurement of the nuclear material quantity in a spent fuel assembly would be performed before the assembly was transferred into the consolidation process area and the quantity of nuclear material in each consolidation canister would be measured after it was filled and transferred out of the consolidation process area. However, the time required to measure each fuel assembly and consolidation canister, the complexity of the operation and calibration of the measurement equipment, and the undetermined errors in the accuracy of the measurements make the practicality of this safeguards approach doubtful.

\subsection{PERIMETER SAFEGUARDS SYSTEM}

A perimeter safeguards system would consist of procedures and techniques that monitor the fuel assemblies into, and all material flows out of, the consolidation process area. Nuclear material should be transferred out of the process area only in authorized containers. Safeguards procedures would be applied to these containers, and all other containers, on exit from the process area.

In the dry consolidation process, the spent fuel assembly is contained in a hot cell before disassembly operations. The containment offered by a hot cell could be used as part of the safeguards system. All process operations where single fuel pins were accessible would be performed in the hot cell area. In the dry consolidation process described in Sect. 3, the spent fuel assembly would be transferred intact through an entry port into the consolidation process hot cell. The spent fuel pins would be transferred through an exit port into a consolidation canister. A combination of surveillance techniques and nuclear material verification techniques would be required at all entry and exit ports to the hot cell operation. The effectiveness of this approach relies on verification of facility design to ensure that no undisclosed, and unmonitored, entry or exit ports exist in the hot cell walls.

In the wet consolidation process, the storage pool itself offers considerable protection from diversion in the form of containment. The safeguards surveillance equipment currently used could monitor the surface of the pool to ensure that no unauthorized removal of material takes place. All containers and other items removed from the storage pool would have to be monitored for nuclear material. The special equipment required for dismantling the spent fuel assembly also could be monitored to ensure that all operations were recorded.

An example of potential safeguards actions for a perimeter safeguards system around the consolidation process is given below. 
1. Fuel assembly entry point. Each fuel assembly would be verified by serial number and a nondestructive assay (NDA) attribute measurement when it was transferred to the consolidation equipment or hot-cell.

2. Consolidation canister exit point. After each consolidation canister was filled, it would be removed from the consolidation equipment or transferred through the hot cell exit port and sealed under surveillance.

3. Waste package exit points. All waste packages leaving the storage pool or hot cell would be monitored for specific gamma or neutron emissions to ensure that they did not contain nuclear material.

4. Broken fuel pins and pellets. Broken fuel pins, pellets and any other material containing nuclear material would be transferred to casks and treated as consolidated spent fuel pins for safeguards purposes.

After the full consolidation canisters and other nuclear material containing packages are removed from the exit port, they would be under continuous surveillance until sealed and stored. Surveillance after sealing may be required, depending on the reliability of the sealing technique and whether redundant safeguards monitoring techniques are implemented."

Assuming that (1) the integrity of the fuel assembly has been maintained, or the fuel assembly nuclear material content can be verified before transfer to the consolidation process area, and (2) all potential exit ports are monitored for nuclear material transfers, then a perimeter safeguards system could provide a high level of assurance that no diversion of nuclear material has taken place. The perimeter safeguards approach has at least two major advantages: (1) it would be less intrusive on faeility operations than a pin-tracking approach (i.e. safeguards inspections would not require access to the consolidation process area or equipment), and (2) the safeguards techniques and equipment required are, in many cases, currently in use and readily available. This approach, however, has several serious weaknesses: (1) if the surveillance and/or monitoring system fails, reestablishment of safeguards assurance will be virtually impossible because of the lack of inventory data; (2) the quantity of spent fuel processed would not be verified; and (3) the IAEA safeguards significant quantity and timeliness criteria would be difficult, if not impossible, to apply.

\subsection{PIN-TRACKNNG AND VERIFICATION SAFEGUARDS SYSTEM}

In a pin-tracking and verification safeguards system, the spent fuel pins would be tracked from the fuel assembly through the consolidation process and into the consolidation canister. To track the spent fuel pins and to ensure that all pins were received and transferred to a consolidation cask, some means of verifying individual fuel pins will be necessary. A safeguards system will be required that has the capability to verify receipt of all spent fuel pins and to track the pins throughout the process from the time they are pulled from the assembly until they are sealed in the consolidation canister. Examples of safeguards action points in the consolidation process for a pin-tracking and verification safeguards system are listed below.

1. Verification of assemblies on transfer to the consolidation area. Fuel assemblies would be verified when transferred to the consolidation equipment or hot cell by serial number identification and the shipper's data. The shipper's data should completely describe the assembly including number and location of all fuel pins.

2. Verification of fuel pins in the assembly. After the top of the assembly is removed, the number and location of fuel pins would be verified. (Techniques and/or equipment for this 
verification are not currently available. Possibilities include infrared imaging or collimated neutron counters.)

3. Tracking fuel pins during consolidation. The pins would be monitored (e.g., by NDA) to verify presence of spent fuel and tracked as they were removed from the assembly and transferred to the consolidation canister. The location of each pin and number of pins in each canister would be recorded.

4. Verification of fuel pins in the consolidation canister. The number of fuel pins in the canister would be verified before closing and sealing the canister (equipment development necessary as in step 2).

5. Verification of consolidation canisters during storage. The seals on the canisters would be verified on a routine inspection basis to verify integrity.

6. Monitoring of nonfuel-bearing components and process waste. The material being placed in each nonfuel-bearing canister and process waste container would be monitored to detect presence of nuclear material as it was transferred to the canister or container. Each container would be under surveillance until filled and sealed.

Once the consolidation canisters were filled, sealed, and removed from the consolidation hot cell, the safeguards procedures applied could be essentially those currently applied to spent fuel assembly storage areas. ${ }^{10}$

The pin-tracking approach has several safeguards advantages: (1) it provides a record of the quantity of spent fuel received and processed at the facility, (2) any diversions of significant quantities of nuclear material should be detected on a timely basis, (3) the safeguards system could possibly use the facility accounting system in several areas, and (4) the IAEA significant quantity and timeliness criteria could be applied if required. The disadvantages of the pin-tracking approach lie primarily in the complexity of the equipment and procedures required to implement the system. Development of new attributes measurement equipment would be required for pin verification. An automated data input and record keeping system would be required for the safeguards verification activities. Development and maintenance of the equipment and procedures required could be costly and manpower intensive.

\subsection{EVALUATION OF POTENTIAL SAFEGUARDS APPROACHES}

The safeguards approaches outlined in Sect. 6.2 will require material verification and/or continuous monitoring and surveillance techniques more advanced than those currently in use to provide an adequate level of safeguards in the consolidation process area. The potential safeguards techniques that could be applied in the operating areas of a spent fuel consolidation facility are listed and discussed briefly in Appendix A.

In the perimeter safeguards system, safeguards verification to ensure that no holes exist in the perimeter boundary will be required during facility design and construction; in addition, all entry and exit points will have to be continuously monitored to ensure that no nuclear material leaves the consolidation process area without being declared. Highly reliable monitoring systems to detect nuclear material in a variety of containers would be required in such a system. Although monitoring of the process exit and entry points, coupled with surveillance of receiving, storage, and shipping areas could be considered to provide adequate safeguards, any failure in the system could result in safeguards failure. Redundant and independent systems would be necessary to provide adequate safeguards assurance. ${ }^{11}$ 
In the pin-tracking and verification safeguards approach, after the end cap is removed from the assembly and the fuel pins are exposed, a technique for verifying which pins are spent fuel pins before the pins are extracted from the assembly might be necessary to verify the fuel assembly shipper's data. Because the assembly may contain nonfuel-bearing pins that look like fuel pins, the technique must be able to differentiate between the fuel-bearing pins and those which do not have fuel and to ensure that all fuel-bearing pins are received and extracted from the fuel assembly. If this capability were available, the need for additional NDA measurements of the fuel assembly for material accountancy could be supplanted. Equipment to verify the spent fuel pins as they are extracted from the assembly and as they are transferred to the consolidation canister also will be required. Several candidate techniques that could be explored for potential applications to these needs are neutron counting, thermal detectors (i.e., infrared sensors), serial number identification for each pin, and pin weight.

Both the pin-tracking and perimeter approaches have weaknesses. In the perimeter approach, if the monitoring and surveillance system failed, or the surveillance data were irretrievably lost, reestablishment of credible safeguards would be virtually impossible. The pin-tracking approach is dependent on (1) manual data entry by the operator or an automated data entry system for reliable data input and (2) a secure data processing and recording system for reliable safeguards information. A failure in any part of the data system could result in a safeguards failure. The pin-tracking approach also would be technically complex and costly to implement and somewhat intrusive on operation of the facility.

A safeguards system that uses aspects of both the pin-tracking approach to verify the spent fuel received and transferred out of the consolidation area, and the perimeter approach to detect unauthorized removal could result in a more reliable and efficient safeguards system. A knowledge of the quantity of spent fuel in the consolidation area could provide backup and recovery data if the perimeter system failed and, thereby, could reduce the requirement for redundant and independent monitoring and surveillance systems in a perimeter-only safeguards system.

An "equipment monitoring" safeguards approach is also a possibility for complex operations such as those required in a fuel consolidation facility. Movements of the process equipment required to transfer and to consolidate the spent fuel assemblies and pins could be monitored using "artificial intelligence type" computer programs, and compared to the normal operating procedures to detect any anomalous operations that might indicate possible diversion of spent fuel from the authorized location.

\section{SUMMARY AND CONCLUSIONS}

In selecting safeguards approaches for a spent fuel consolidation facility, the answers to questions raised by the key safeguards issues introduced are important and are addressed in the following discussion.

1. Will dismantling of the spent fuel assemblies require measurement of the nuclear material for material accountancy?

Measurement of the fuel assemblies to determine the nuclear material content will not be required assuming that (1) continuous knowledge of the fuel assembly integrity has been preserved, and (2) an adequate safeguards system is provided for the consolidation process area. Assurance must be provided that all the nuclear material actually was received by the consolidation facility. Once this assurance is provided, additional measurements for quantity of nuclear material would not be critical to safeguards of the spent fuel. When these conditions are met, measurements of nuclear 
material quantity for the majority of fuel assemblies should not be required. In cases where the integrity of the fuel assembly as received is in question because of (1) loss of safeguards assurance, (2) fuel pin reconfiguration, and/or (3) unavailability of manufacturer or reactor data, a measurement of nuclear material content of the fuel assembly may be required to reinstate material accountancy before dismantling the fuel assembly. Because the possibility exists that spent fuel assemblies may be received with no safeguards assurance and/or knowledge of the nuclear material content, the capability to measure the quantity of nuclear material in a fuel assembly, a canister of consolidated spent fuel pins, and individual fuel pins should be provided at the consolidation facility.

The answer to this question also involves whether the basis for safeguarding spent fuel should be material accountancy or whether a continuous knowledge approach based on item tracking is adequate for the spent fuel pins after consolidation. In a consolidation process with a safeguards accountability system that tracks the location and disposition of each pin, the nuclear material content of each consolidation canister would be calculated, final disposition of the nuclear material could be recorded, and the material accountancy system would be intact. Where the safeguards system for the consolidation process does not keep records of individual fuel pins, but does provide assurance that all fuel pins are transferred to consolidation canisters, item accountancy of consolidation canisters and storage casks could provide assurance that no diversion has taken place and material accountancy may no longer be required.

In either case, assurance that the nuclear material is received at the consolidation facility either by continuous knowledge or reverification of the fuel assembly is necessary. Many reactors are currently reconstituting fuel in assemblies to attain additional burnup, and the safeguards accounting concerns for these reconstituted assemblies will need to be addressed.

2. - Can a safeguards system be devised that does not require verification of individual spent fuel pins?

Verification that the pins contain nuclear material may not be required. A perimeter safeguards system, such as the one in the example system presented in Sect. 6 , could be devised that would not require verification of individual spent fuel pins. However, a major weakness of this system is the reliance on monitoring equipment that has yet to be implemented for all the safeguards applications involved. Some combination of the perimeter and the pin tracking and verification safeguards approaches might be required for reliability. A combination of a perimeter system that monitors all material flows from the consolidation process and an internal system that provides continuous tracking of all pins until the pins are sealed in canisters could provide adequate safeguards assurance without verification of individual pins.

3. Can safeguards systems for consolidation facilities be as effective as those currently used for spent fuel assemblies?

This involves identification of safeguards requirements and development of techniques and equipment to meet these requirements. The principal safeguards issue is providing the assurance that all pins removed from the received fuel assemblies are transferred to, and sealed in, the consolidation canisters or nuclear material waste canisters. Containment, surveillance, and monitoring techniques and/or accounting systems that can provide this assurance have yet to be identified. The safeguards techniques must (1) track individual fuel pins through the consolidation process and verify that no substitution occurred, and/or (2) treat the consolidation cell as a black box and verify that nuclear material does not leave the cell except through declared transfers. 
4. Can the level of safeguards effectiveness required be provided with the sateguards techniques currently available?

The consolidation process complicates the safeguards requirements by preventing use of the fuel assembly for item accountability and by providing access to individual fuel pins. The safeguards techniques currently used for spent fuel assemblies will be applicable in receiving and storage areas of consolidation facilities. New safeguards techniques will be required for the consolidation process area. The complex equipment movements and multiple operations necessary to remove and to transfer the fuel pins from assemblies to the consolidation and nonfuel-bearing canisters may preclude effective use of current surveillance techniques for the fuel pin consolidation operation. To provide the safeguards effectiveness and reliability required and to keep inspector manpower costs and facility intrusion at an acceptable level, development of (1) redundant-automated verification and surveillance equipment, (2) new techniques and equipment for verification of fuel assemblies and spent fuel pins by attributes measurement, and (3) techniques to monitor consolidation and waste canisters for nuclear material will be required.

In summary, the spent fuel consolidation process introduces new concerns for safeguards that will require further development of existing safeguards techniques. Development of new safeguards approaches may be required to provide adequate safeguards systems for the consolidation process area. No unsolvable technical problems appear to exist in adapting current safeguards techniques or in the development of new equipment and procedures to provide safeguards assurance for fuel consolidation facilities. In consolidation facilities, because the fuel pins are long and awkward to conceal and contain only a small quantity of plutonium, assurance that no undeclared nuclear material leaves the consolidation process area could provide safeguards assurance that no nuclear material has been diverted. However, this approach would be very vulnerable to equipment failure. A combination approach that provides verification of inventory and perimeter monitoring would provide a more reliable safeguards system. Any safeguards approach that relies entirely on installed safeguards equipment will be vulnerable to equipment failures to some extent. Thus, other safeguards approaches such as analysis of (1) the consolidation facility operating data to detect anomalies in operating procedures that could indicate safeguards problems, and (2) the data from other related facilities (i.e. reactors, fuel fabricators) also should be evaluated when a safeguards system for a specific consolidation facility is in the design phase. 
• 


\section{REFERENCES}

1. Advisory Group Meeting on Safeguards Related to Final Disposal of Nuclear Material in Waste and Spent Fuel (AGM-660), STR-243 (revised), International Atomic Energy Agency, Vienna, December 1988.

2.A. Fattah and N. Khlebnikov, International Safeguards Aspects of Spent Fuel in Permanent Geological Repositories, IAEA Bulletin Vol. 32, No.1, 1990, International Atomic Energy Agency, Vienna, 1990.

3. K. K. S. Pillay and R. R. Picard, International Safeguards Relevant to Geologic Disposal of High-Level Wastes and Spent Fuels, Vol. 1 Proceedings of the ANS International Topical Meeting, Las Vegas, Nevada, April 8-12, 1990.

4. F. P. Roberts, N. L. Harms and R. A. Libby, Safeguards Aspects of Spent Fuel Rod Consolidation (draft), Battelle Northwest Laboratories, Pacific Northwest Laboratory, Richland, Washington, March 1987.

5. K J. Swyler and Sidney Fiarman, International Safeguards Considerations in DOE Commercial Spent Fuel Management. TSO No. 86-24. Brookhaven National Laboratory, Upton, New York, September, 1986.

- 6. B. W. Moran, et al., Safeguards and Security Recommendations for the OCRWM Federal Waste Management System, K/TP-192, Martin Marietta Energy Systems, Inc., Oak Ridge Gaseous Diffusion Plant, August, 1989.

7. M. W. Fisher, Dry Rod Consolidation Advancements in the OCRWM Programs, Journal of the Institute of Nuclear Materials Management XVI(3), p,15, 1988.

8. C. W. Forsberg, Spent Fuel Reconstitution, Consolidation, and Disassembly, K/TTP-361, Martin Marietta Energy Systems, Inc., Oak Ridge National Laboratory, December 1990. 1990.

9. Fuel Master, the Complete Consolidation Solution B\&W Company, Lynchburg, Virginia,

10. Safequards of Spent Fuel Storage Area in Large Scale reprocessing Plants, LASCAR Working Group N.1 Report, June 1990.

11. D. D. Drayer, C. S. Sonnier and D. L. Mangan, Redundant and Independent Containment and Surveillance Systems, ISPO-314, Sandia National Laboratories, Albuquerque, New Mexico, 1990 
0

0

0

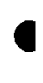




\title{
ACRONYMS AND INTITIALISMS
}

\author{
BWR boiling water reactor \\ GWd Gigawatt-day \\ IAEA International Atomic Energy Agency \\ LASCAR Large Scale Reprocessing Plant Safeguards \\ LWR light-water reactor \\ MTIHM metric tons initial heavy metal \\ NDA nondestructive assay \\ PWR pressurized water reactor
}





\section{APPENDIX A.}

Potential applications of safeguards techniques in a spent fuel consolidation facility are listed in Table A.1. The list is intended to identify candidate techniques that could be included, if required. in each operating area and is not intended to be comprehensive or to define a consolidation facility safeguards system. In this list, an attributes measurement is considered to be a Cerenkov Glow observation, a gross neutron or gamma measurement, or any other technique that confirms the presence of spent fuel pins or assemblies. In the receiving and storage area, the safeguards techniques currently in use at reactor fuel assembly storage areas would be applicable or could be adapted for use in spent fuel casks and assembly storage areas. In the consolidation process area, the safeguards techniques and/or equipment may not be available or the equipment currently in use may not be directly applicable and development efforts, in most cases, will be required. In the cask storage and shipping area, the safeguards techniques currently in use for fuel assemblies at reactor storage areas would generally be applicable or casily adapted for verification of the consolidation canister storage casks.

\section{RECEIVING AND STORAGE}

The safeguards techniques listed for this area are those developed and in use for spent fuel assemblies in storage, except for the attributes measurement. In wet storage pools, the Cerenkov Glow technique is normally used as an attributes check. In the cask receiving and unloading areas and in facilities having dry storage for fuel assemblies, a gross neutron or gamma measurement could serve as an attributes measurement. The LASCAR working group report discusses safeguards equipment available for these areas. ${ }^{10}$

\section{CONSOLIDATION AREA}

The safeguards techniques listed for this area include several that will require development efforts. A technique to verify that all the spent fuel pins are in the fuel assembly when the end cap is removed may be required. Techniques that have possibilities for application here are radiography, infrared sensors, collimated neutron detectors, and visual inspection. An attributes measurement to verify individual fuel pins may be required to verify the fuel pins as they are removed from the assembly. Techniques that have possibilities for application here are collimated neutron sensors and thermal sensors. Although serial number is listed in the table as a possible verification technique for fuel pins, reading the numbers on individual pins may be difficult, as well as time consuming, and may provide less safeguards assurance than an attributes measurement. The use of currently available surveillance techniques in this area will be difficult because of the complex operations and equipment movement. Development of advanced surveillance techniques coupled with equipment monitoring may be necessary to provide a reliable and efficient surveillance system. Nuclear material monitors at material exit points from the process may be required in consolidation facility safeguards systems. Although monitors are available and currently used to monitor portals and packages for nuclear material, development efforts will be required to adapt the monitors to the material and packages specific to consolidation facilities. 
Tablo 4.

Table A1. Poleotial enfegunds techniques for spent auclear fuel consolidation Encilitios

\begin{tabular}{|c|c|c|}
\hline Operatung area & Safeguards concerns & Safeguards technique \\
\hline & Receiving and srorage & \\
\hline Cask recernng & Suniching casto & $\begin{array}{l}\text { Serial number } \\
\text { Seal cheek } \\
\text { Attnbutes measurement }\end{array}$ \\
\hline Cask storage & Swntching castos & $\begin{array}{l}\text { Survesilance } \\
\text { Senal number } \\
\text { Seal check }\end{array}$ \\
\hline Cask unloading & Fuel assembly swiching & $\begin{array}{l}\text { Serial number } \\
\text { Attributes measurement } \\
\text { NDA of assembly }\end{array}$ \\
\hline \multirow[t]{2}{*}{ Assembly storage } & $\begin{array}{l}\text { Fuel assembly integrity and } \\
\text { swiching }\end{array}$ & $\begin{array}{l}\text { Surveiliance } \\
\text { Serial number } \\
\text { Attnbutes measurement } \\
\text { Weight Verification }\end{array}$ \\
\hline & Consolidation area & \\
\hline Removal of end cap & $\begin{array}{l}\text { Verification that } \\
\text { all fuel pins were } \\
\text { recerved }\end{array}$ & $\begin{array}{l}\text { Visual inspection } \\
\text { Infrared sensors } \\
\text { Neutron measurements }\end{array}$ \\
\hline Pin extraction & Diversion of fucl pins & $\begin{array}{l}\text { Surveillance } \\
\text { Altributes measurement } \\
\text { Serial number } \\
\text { NDA of pins } \\
\text { Pin Counting } \\
\text { Equipment Montoring }\end{array}$ \\
\hline Lag storage & Diversion of fucl pins & Surveillance \\
\hline $\begin{array}{l}\text { Consolidation } \\
\text { process }\end{array}$ & $\begin{array}{l}\text { Verification of fucl pin } \\
\text { transfer }\end{array}$ & $\begin{array}{l}\text { Surveillance } \\
\text { Attributes measurement } \\
\text { Serial number } \\
\text { Pin Countung } \\
\text { Equipment Monitoring }\end{array}$ \\
\hline \multirow[t]{2}{*}{$\begin{array}{l}\text { Broken pin and } \\
\text { waste packaging }\end{array}$} & Diversion of pins & $\begin{array}{l}\text { Nuclear material } \\
\text { monitors }\end{array}$ \\
\hline & Storage and shippung & \\
\hline Canister storage & $\begin{array}{l}\text { Canistcr integnty } \\
\text { swhtching canisters }\end{array}$ & $\begin{array}{l}\text { Surveillance } \\
\text { Serial number } \\
\text { Attributes measurement } \\
\text { Weight Verification }\end{array}$ \\
\hline Cask loading & Switching canisters & $\begin{array}{l}\text { Serial number } \\
\text { Attributes measurement }\end{array}$ \\
\hline Cask sealing & $\begin{array}{l}\text { Diversion/swiching } \\
\text { canisters }\end{array}$ & $\begin{array}{l}\text { Surverllance } \\
\text { Seal check }\end{array}$ \\
\hline Cask storage & Swiching casks & $\begin{array}{l}\text { Surveilance } \\
\text { Seal check }\end{array}$ \\
\hline
\end{tabular}




\section{STORAGE AND SHIPPING}

The techniques listed for this area are similar to those required in the receiving and storage area. However, the consolidation casks may be placed in long-term storage in a geologic repository; therefore, consideration should be given to using a sealing technique that provides positive cask identification as well as verification of cask integrity. 